\title{
An attempt to assess the ecological status of a lake based on historical and current maps of submerged vegetation
}

\author{
Andrzej Hutorowicz, Marcin Białowąs, Bronisław Długoszewski, Lech Doroszczyk
}

Received - 31 January 2017/Accepted - 28 March 2017. Published online: 31 March 2017; @Inland Fisheries Institute in Olsztyn, Poland Citation: Hutorowicz A., Białowąs M., Długoszewski B., Doroszczyk L. 2017 - An attempt to assess the ecological status of a lake based on historical and current maps of submerged vegetation - Arch. Pol. Fish. 25: 33-42.

\begin{abstract}
The possibility of doing a back assessment of the ecological status of a lake based on archival bathymetric maps indicating areas overgrown with rushes and aquatic vegetation was verified. This assessment was assumed to be in accordance with that performed with the official Polish macrophyte-based method for lake assessment (Ecological State Macrophyte Index, ESMI). The study was conducted on Lake Dobrag located in the Warmian-Masurian Voivodeship (surface area -108 ha, maximum depth $-27.9 \mathrm{~m}$, mean depth $-11.6 \mathrm{~m}$ ). It included the hydroacoustic distribution of submerged macrophytes along 85 evenly distributed belt transects (perpendicularl to the shore line), creating a bathymetric chart and maps of vegetation occurrence and identifying areas occupied by hydrophytes $\left(\mathrm{C}_{\max }\right)$ and the maximum depth of lake colonization (Z). Analogous data were read from archival bathymetric chart dating from 1964-1968. The values obtained were compared with the means (and their confidence intervals) of 83 stratified lakes in Poland in different ecological status classes. Analysis of changes indicated that the ecological status of the lake had deteriorated. In the mid-1960s, the status of the lake was less than "very good" while the current status borders between "good" and "moderate." The results indicate that the proposed method could be useful when attempting to assess changes in ecological status using archival bathymetric charts showing areas overgrown with vegetation and the distribution of it in lakes.
\end{abstract}

Keywords: hydroacoustics, aquatic vegetation, assessing ecological status

\footnotetext{
A. Hutorowicz [ $\Xi^{-}$], M. Białowąs, B. Długoszewski, L. Doroszczyk Hydroacoustic Laboratory, Inland Fisheries Institute in Olsztyn, Poland

e-mial: a.hutorowicz@infish.com.pl
}

\section{Introduction}

The Water Framework Directive (WFD EU, 2000) required EU member states to create national systems for assessing the ecological status of lakes based on biological elements, including macrophytes. Prior to 2004, when in Germany the first European assessment method was published (Schaumburg et al. 2004), vegetation studies were conducted in many countries with many different methods and only in chosen lakes (Knoben et al. 1995). The floristic composition of the entire area of the lake was analyzed, as were vegetation associations and sigma-associations and landscape phytocomplexes. Vegetation was examined in selected locations that were typical of lakes, and aerial photographs were also used (Ciecierska et al. 2013).

The national systems for assessing the ecological status of lakes developed in the early 2000s in accordance with the requirements of the WFD include many different indicators that describe the taxonomic composition and spatial structure of vegetation. This group considers, among other things, the maximum depth distribution of macrophytes and the mean depth of vegetation. A distinct dependence between these parameters and phosphorous concentrations in the water has been demonstrated (Free et al. 2006).

(C) Copyright by Stanisław Sakowicz Inland Fisheries Institute in Olsztyn.

(C) 2017 Author(s). This is an open access article licensed under the Creative Commons Attribution-NonCommercial-NoDerivs License (http://creativecommons.org/licenses/by-nc-nd/3.0/). 
In Poland, part of the Rejewski method, which includes assessing synathropization, became the basis for the ESMI method that was adopted in 2008 for official lake monitoring (Ciecierska et al. 2013, Kolada et al. 2014). Rejewski (1981) proposed a method for assessing lakes based on the structural-spatial systems of the phytolittoral vegetation that took into consideration the ecological dependencies of the macrophytes. Rejewski differentiated the natural process of lake succession from the anthropogenic process of synathropization and created two separate classifications. Lake assessment is based on the phytocenotic diversity index $\mathrm{H}$ (calculated with the Shannon-Wiener formula) and the colonization in$\operatorname{dex} Z$, which determines the ratios of total surface covered by vegetation to the area that is potentially available to the plant. The original Rejewski method also takes into consideration the maximum depth of occurrence of vegetation in the lake $\left(\mathrm{C}_{\max }\right)$ and water transparency measured with a Secchi disc (SD).

In the early 2000s, the creation of national systems for assessing ecological status compelled researchers to search for lakes that were still in reference states, although the WFD does permit the use of historical data. In light of this, it was justified to develop the possibility of determining the likely ecological status of a lake, for example, in the mid twentieth century, based on available information (bathymetric charts at the Inland Fisheries Institute). The comparisons were made using the following indicators that were estimated based on bathymetric charts and contemporary research: maximum depth of vegetation occurrence in the lake $\left(\mathrm{C}_{\max }\right)$, water transparency measured as Secchi depth visibility (SDV), and colonization index (Z). The aim of the present paper was to attempt to assess changes in the lake's ecological status based on historical and contemporary vegetation maps of the lake.

\section{Materials and methods}

\section{Study area}

The study was conducted on Lake Dobrąg, which is located $5 \mathrm{~km}$ to the east of Barczewa in the Olsztyn
Lake District. The lake is thermally stratified and has a surface area of $108 \mathrm{ha}$, a maximum depth of 27.9 $\mathrm{m}$, and a mean depth of $11.6 \mathrm{~m}$. The lake is supplied by several small streams, and water flows out of it through the Dobrążka stream to the Pisa River. According to data from the Voivodeship Inspectorate of Environmental Protection in Olsztyn, the lake's immediate drainage basin has a surface area of $96 \mathrm{ha}$, of which $56 \%$ is forested, $20 \%$ is agricultural, $16 \%$ is pasture, and $4 \%$ is unused. The lake's morphometric-drainage conditions permit it to be classified as a category I basin, which means that it is least susceptible to degradation (Budzyńska 2007). In the 1980s, the lake did not receive inputs sewage from point source pollution and it was not exploited for tourism (Cydzik and Soszka 1988). The entire water body of PLRW70001858445929, which includes Dobracg Canal and Lake Dobragg, meets the requirements of the Water Framework Directive with regard to point source pollution and non-point source pollution, including with nitrates (RODW 2005). Based on a study conducted in 1981 and according to the System for Assessing Lake Quality, which was then in force, Lake Dobrąg was assessed as "nonclassified"; however, according to the modified system, it was assessed to be class III water purity. The reason for this was low oxygen saturation in hypolimnion waters (6\%), and very high levels of phosphate phosphorus and iron in the near-bottom water layers. Water transparency in summer was $1.7 \mathrm{~m}$ (Cydzik and Soszka 1988).

\section{Cartographic measurements}

The data regarding the surface area and distribution of vegetation in Lake Dobrag in the 1960s was obtained by measuring the surface area occupied by hydrophytes and the distances of the distribution limits of submerged macrophytes from the shoreline on historic bathymetric charts. The charts do not include information on the dates the vegetation was studied; however, based on the date that the report entitled "Principles for a fisheries management project for Lake Dobrąg” (March 1969) was compiled 
and integral parts of which included the map mentioned above and the bathymetric chart (produced based on measurements performed in January 1964). Thus, the hydrophyte studied must have been conducted between 1964 and 1968 (Fisheries Management Project 1969). The bathymetric chart was drawn based on measurements done in February 1965 using the method of squares with $50 \mathrm{~m}$ sides, as described by Kondracki (1953). The chart shows the surface area (and reach) occupied separately by rushes and submerged hydrophytes.

The surface occupied by rushes and submerged macrophytes was measured directly from the bathymetric chart (the module that permitted measuring the surface area of fields) after it had been digitized with the measuring program Multiscan by Computer Scanning Systems (Poland). The mean depth of hydrophyte occurrence based on the historic bathymetric chart was determined using 85 belt transects distributed evenly around the lake shore. The same number of transects was used as in hydroacoustic studies conducted in 2016. This number is seven times greater than the minimum number of transects required by the formula developed by Jensen (1977), which is based on lake area and shoreline length. The depth of macrophyte occurrence was calculated based on the lake bottom profiles made along each transect. The bottom profile was created by placing within the coordinate system the distance of the intersection point of the transect line with subsequent isobaths from the shoreline.

The depth at which hydrophytes occurred $\left(\mathrm{C}_{\max }\right)$ in the 1960s was determined by extrapolating the depths between known isobaths neighboring the outer limits of submerged macrophytes occurrence. The method used to estimate the depth at which hydrophytes occurred was assessed by determining the mean error for this type of procedure for the data from 2016, when measurements of the depths of submerged vegetation were available (read from echograms). Because the depths of occurrence of elodea differed in each profile, the relative error (TM) was determined for the maximum colonization depth $\left(\mathrm{C}_{\max }\right)$, as follows:

$$
T M=\frac{\sum_{1}^{n} \frac{\Delta \mathrm{X}_{i}}{\mathrm{X}_{i}}}{n}
$$

where $\mathrm{M}$ is the value of the relative error, $\mathrm{X}_{\mathrm{i}}$ is the maximum colonization depth on the $\mathrm{i}$-th profile determined from the echogram, $\Delta \mathrm{X}_{\mathrm{i}}$ is the difference between the maximum colonization depth on the $\mathrm{i}$-th profile determined based on the echogram and the interpolation procedure from the bathymetric chart (absolute measurement error on the i-th profile). The colonization index $\mathrm{Z}$, calculated according to the formula by Rejewski (1981), is as follows:

$$
Z=\frac{N}{P-P_{\text {isob. } 2.5}}
$$

where $\mathrm{Z}$ - the colonization index, $\mathrm{N}$ - lake surface are covered by vegetation, $\mathrm{P}$ - lake surface area

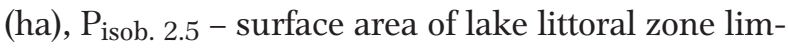
ited by the $2.5 \mathrm{~m}$ isobath (ha).

\section{Hydroacoustic measurements}

Hydroacoustic measurements were conducted from July 27 to August 3, 2016. They included measurements of bottom depth, maximum depth of submerged macrophyte occurrence, and height of submerged hydrophytes at sounding points. Hydroacoustic measurements of submerged macrophytes were taken with a SIMRAD EK60 echo sounder at a frequency of $120 \mathrm{kHz}$. The lake was surveyed along belt transects that were perpendicular to the shoreline at a speed of approximately $0.5 \mathrm{~m} \mathrm{~s}^{-1}$. A GPS receiver was coupled with the echo sounder, which permitted tracking geographical location along with results of the measurements. A second GPS receiver permitted sailing the boat along the planned transects. A short impulse of $0.1 \mathrm{~ms}$ and the maximum frequency of sending single impulses was used. The results of these measurements were saved on the computer hard drive.

The echograms were analyzed in the laboratory with Sonar 5 Pro (Balk and Linden 2008). This program has a module for analyzing the height of submerged macrophytes, which are determined in reference to the identified bottom. This software 


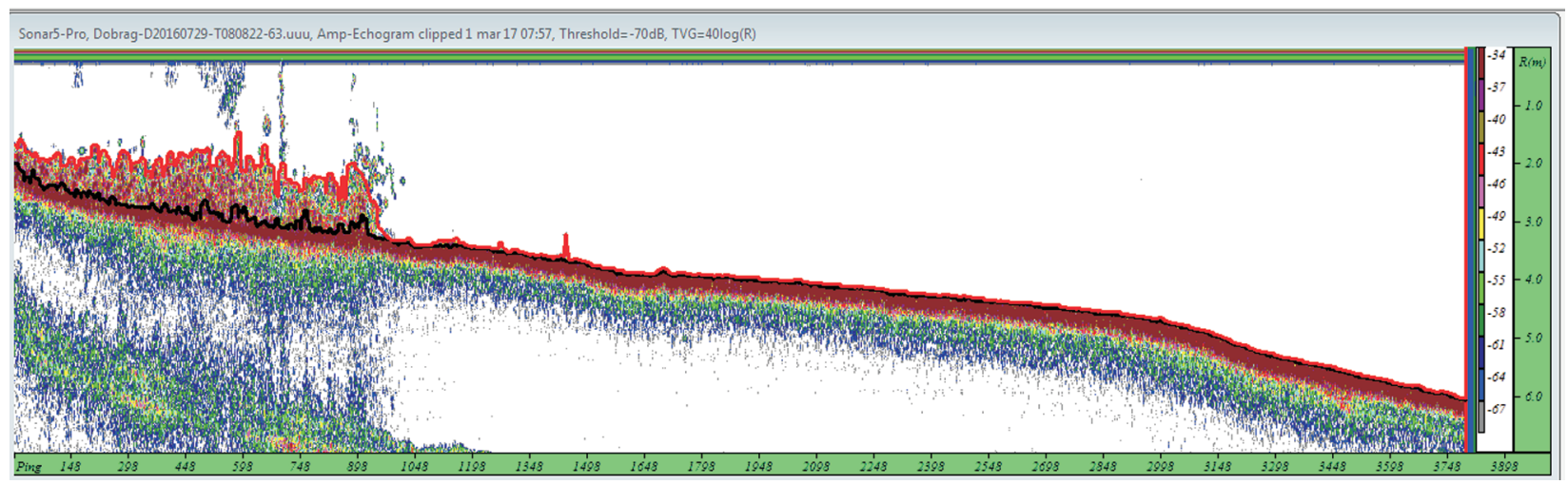

Figure 1. An echogram with the baseline indicated and also the line indicating the distribution of the submerged vegetation registered during the hydroacoustic survey in Lake Dobrąg, July 29, 2016.

allows for automatically creating a line that reflects the surface created by the tops of dense mats of submerged hydrophytes and the line of the lake bottom (Fig. 1). In order to identify submerged hydrophytes, a threshold value of $10 \mathrm{~cm}$ was set, which permitted noting the presence of moss, Fontinalis antipyretica Hedw., in deeper parts of the phytolittoral zone. These data and their analyses provided information on the depth of occurrence and heights of submerged hydrophytes. The degree to which the bottom is covered in profiles was calculated as the share of space with vegetation for all of the places sounded along a given profile.

The submerged hydrophyte distribution map and current bathymetric chart were plotted with the program Surfer by Golden Software (USA). The vegetation map was drawn based on averaged data from segments measuring $0.3 \mathrm{~m}$ (which corresponded to 10 impulses). The area occupied by reeds was drawn with geographic coordinate readings from Internet orthophoto maps using the Geoportal mapping application. Measurements of the surface occupied by hydrophytes and the surface area determined by isobaths on the bathymetric chart were made with the Multiscan measurement program by Computer Scanning Systems (Poland).

Historical and contemporary bathymetric charts were compared by determining the difference in surface area delimited by the $0 \mathrm{~m}, 1 \mathrm{~m}, 2.5 \mathrm{~m}$, and $5 \mathrm{~m}$ isobaths. The depth of hydrophyte occurrence (distribution) and the degree of submerged macrophyte bottom cover was determined directly from digital data on lake depth at given sounding points (so-called base depth) and on the height of vegetation growing on the bottom (so-called bioheight) which were read with Sonar 5 Pro on 85 echograms.

The assessment of the ecological status was done with average values of the colonization index $-\mathrm{Z}$, the maximum depth of vegetation occurrence in the lake $-\mathrm{C}_{\max }$, and the mean visibility of the Secchi disk according to the Rejewski method in individual ecological status classes (1-5) for the stratified Polish lakes reported by Ciecierska et al. (2013).

\section{Results and discussion}

\section{Comparing bathymetric charts}

Bathymetric charts of the lake obtained with data from 2016 (isobaths were determined to a depth of 6 $\mathrm{m}$ ) are presented in Figure 2, while the bathymetric surfaces are in Table 1 . The lake surface area according to the current bathymetric chart is smaller only by 2\% (2.2 ha) than that determined in 1965 based on measurements (Fig. 2). Similarly, the individual bathymetric surface areas analyzed are only less than $3 \%$ smaller. These differences are even smaller when comparing the surface areas of individual isobaths in reference to the surface area of the lake, in which case they differ by less than $1 \%$ (Table 1 ). 
Table 1

Bathymetric surface of Lake Dobrąg based on measurements taken in February 1965 and in August 2016

\begin{tabular}{|c|c|c|c|c|}
\hline \multirow[b]{3}{*}{$\begin{array}{l}\text { Isobath } \\
\text { (m) }\end{array}$} & \multicolumn{2}{|l|}{1965} & \multicolumn{2}{|l|}{2016} \\
\hline & Surface & & Surface & \\
\hline & $\begin{array}{l}\text { Isobath } \\
\text { determined } \\
\text { (ha) }\end{array}$ & $\%$ & $\begin{array}{l}\text { Isobath } \\
\text { determined } \\
\text { (ha) }\end{array}$ & $\%$ \\
\hline 0 & 108.8 & 100.0 & 106.6 & 100.0 \\
\hline 1 & 102.3 & 94.0 & 99.5 & 93.4 \\
\hline 2.5 & 97.2 & 89.4 & 94.6 & 88.8 \\
\hline 5 & 86.7 & 79.7 & 84.2 & 79.0 \\
\hline
\end{tabular}

\section{Surface area occupied and depth of macrophyte occurrence}

The distribution of hydrophytes in Lake Dobrag in the 1960s and currently is presented in Figure 3. The mean depth distribution of vegetation in 1964-1968 was $4.5 \mathrm{~m}$, while it was $3.4 \mathrm{~m}$ in 2016 (Table 2). The reliability test of estimated $C_{\max }$ for the data in

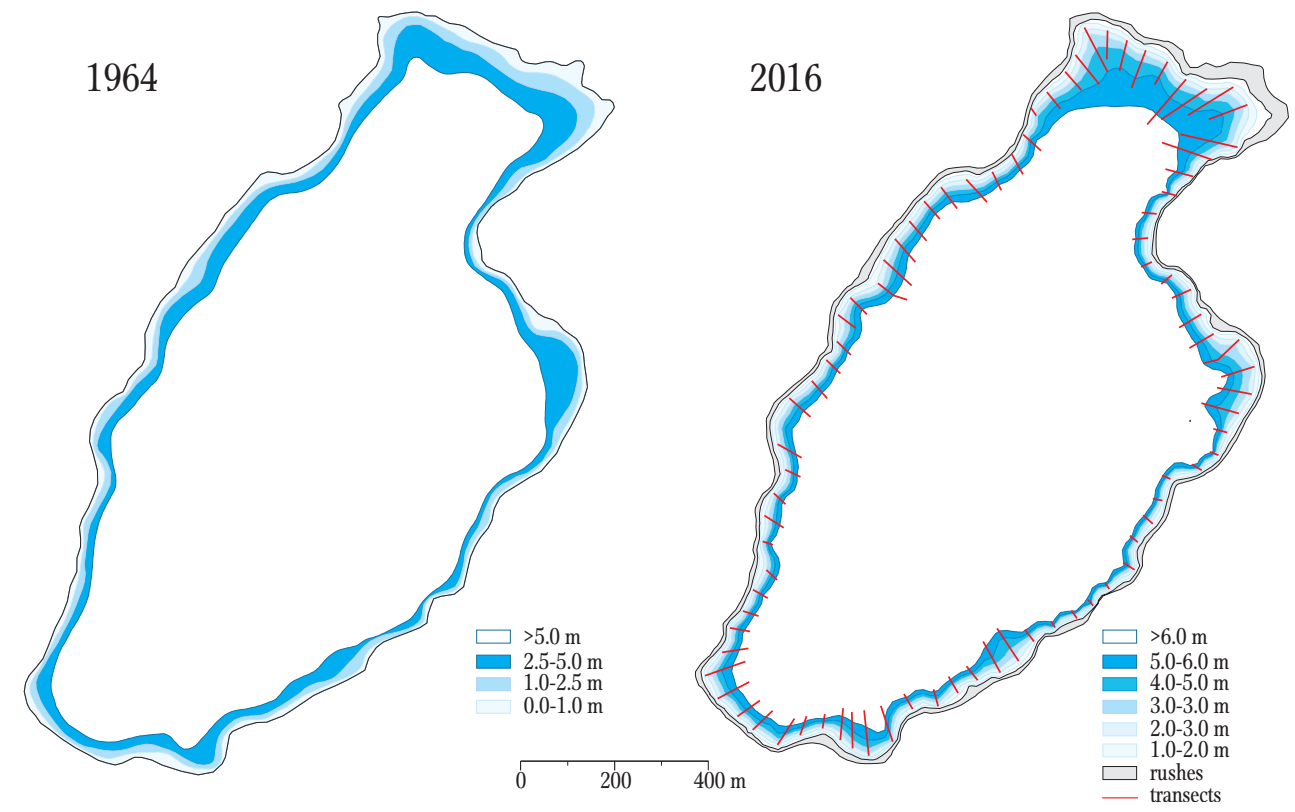

Figure 2. Bathymetric charts of the phytolittoral (to depths of $5 \mathrm{~m}$ ) in Lake Dobrąg based on measurements taken in February 1965 and in August 2016.
August 2016 indicated that there is a slight difference in the means obtained from actual measurements and those estimated with the method accepted for the data from the 1960s. The mean relative error of the estimated colonization depth from the bathymetric chart $(\delta)$ determined based on data from 2016 was $2.6 \%$ (relative error $C_{\max }$ on individual profiles ranged from $-15 \%$ to $+19 \%$, Fig. 4). The mean value of $\mathrm{C}_{\max }$ determined with each method (from echograms and from interpolation among isobaths on the bathymetric chart) differed from each other by just under $9 \mathrm{~cm}$.

The surface are occupied by hydrophytes in 2016 was smaller by $11 \%$ than it was in the 1960 s, and colonization index $\mathrm{Z}$ in 2016 was 1.14, which was about $20 \%$ smaller than the value estimated for the 1960s (Table 2). The percentage cover of submerged macrophytes calculated based on 85 echograms was $79 \%$ in 2016, and this was taken into consideration. Since "Principles for a fisheries management project for Lake Dobrąg” contains no information on lake bottom vegetation cover in the 1960s, the figure presented by Ciecierska (2008) of $86 \%$ was used, which is a mean value for bottom coverage that corresponds to quantity 5 on the Braun-Blaquet 
Table 2

Maximum colonization depth $\left(\mathrm{C}_{\max }\right)$, area of the phytolittoral and colonization index $(\mathrm{Z})$ and Secchi depth visibility (SDV) in Lake Dobrąg based on measurements taken in the mid 1960s and in 2016. SD - standard deviation

\begin{tabular}{llllll} 
& \multicolumn{2}{c}{$\mathrm{C}_{\max }(\mathrm{m})$} & & & \\
\cline { 2 - 5 } Years & Mean (range) & $\mathrm{SD}$ & Area of the phytolittoral (ha) & $\mathrm{Z}$ & $\mathrm{SDV}$ \\
\hline \hline $1964-1968$ & $4.5(0.0-6.8)$ & 1.8 & 19.0 & 1.41 & $3.13^{*}$ \\
2016 & $3.4(2.0-4.4)$ & 0.6 & 16.9 & 1.14 & $1.53^{* *}$ \\
\hline \hline
\end{tabular}

*2.85 $\mathrm{m}$ in $1^{\text {st }}$ September 1964, and $3.4 \mathrm{~m}$ in $19^{\text {th }}$ August 1966, * * $1.36 \mathrm{~m}$ in $3^{\text {rd }}$ August 2016, and $1.70 \mathrm{~m} 30^{\text {th }}$ August 2016

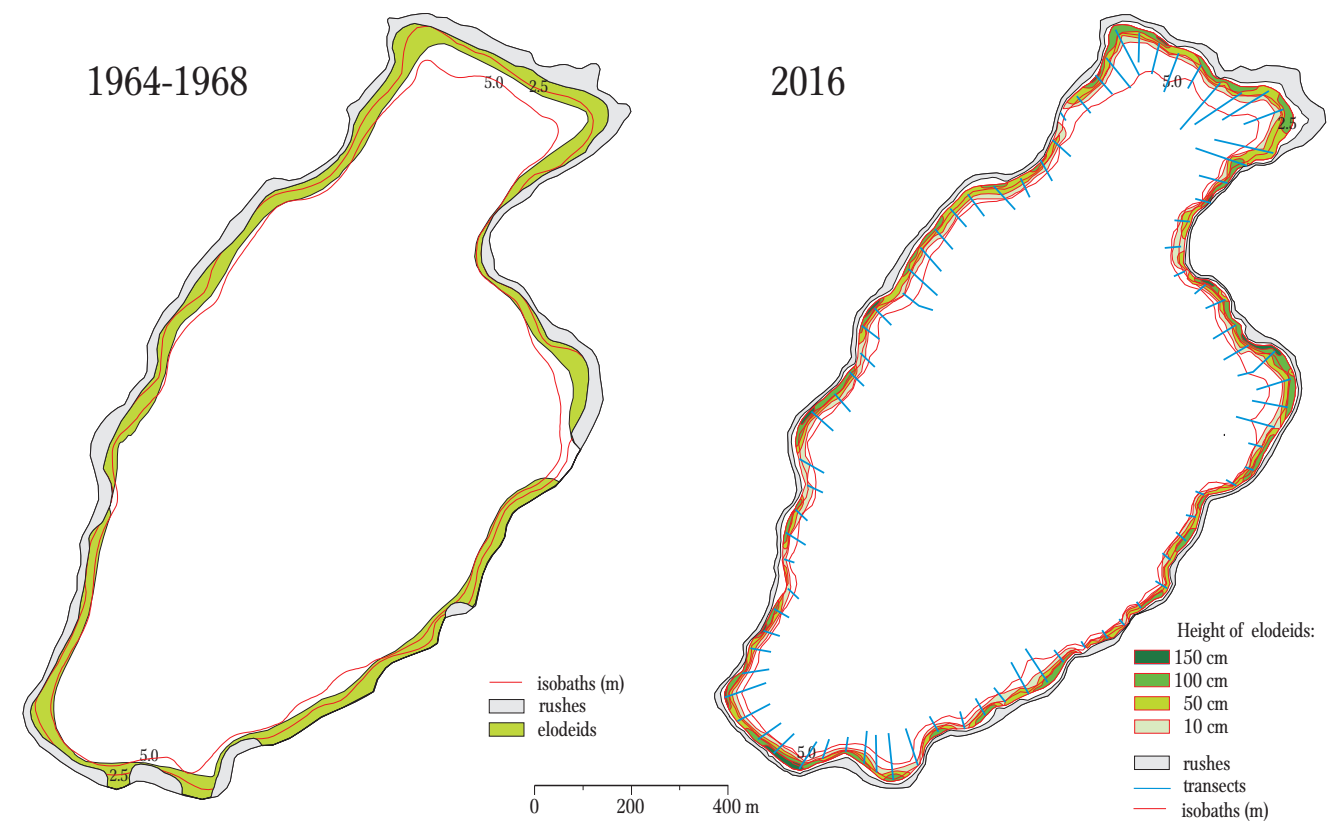

Figure 3. Map illustrating the estimated vegetation distribution in 1964-1968 and in August 2016 (in consideration of their height).

scale. The estimated $\mathrm{C}_{\max }$ and $\mathrm{Z}$ values referred to the values reported by Kolada et al. (2010) for five stratified lakes in the Welski Landscape Park that were studied in 2009 (Fig. 5).

\section{Estimating the ecological status assessment}

Based on the indicators calculated, the most likely assessment of the ecological status of Lake Dobrąg was performed. Since the proper assessment of the lake's ecological status based on macrophytes is only possible using the ESMI multi-component index assessment, which requires providing values for the phytocenotic diversity index $(\mathrm{H})$ and the maximum phytocenotic diversity index $\left(\mathrm{H}_{\max }\right)$, the only action available was to compare the values of the $C_{\max }, Z$, and SDV indexes with the values of these for the different ecological status classes, that are presented in the literature (Ciecierska et al. 2013). In order to estimate the precision and reliability of the assessment of the ecological status, the confidence intervals for the mean values of $\mathrm{C}_{\max }, \mathrm{Z}$, and SDV were determined in ecological status classes calculated for 83 Polish stratified lakes (Fig. 6).

In the 1970s, two of the three analyzed indicators showed that the status was beneath good (<high). The colonization index $\mathrm{Z}$ and mean SDV at a confidence level higher than $99.8 \%$ were smaller than the 
Table 3

Confidence level in accordance with the classification of lakes based on the ESMI indicator assigning Lake Dobrag to an ecological status class based on some of the indicators in the Rejewski method: maximum colonization depth $\left(\mathrm{C}_{\text {max }}\right)$, area of the phytolittoral and colonization index (Z), and Secchi depth visibility (SDV)

Confidence level of assignment to ecological status class (\%)

$\begin{array}{llll}\text { Parameters High } & \text { Good } & \text { Moderate }\end{array}$

Historical state (1964-1968)

$\begin{array}{lll}\mathrm{C}_{\max }(\mathrm{m}) & 96.0 \% & - \\ \mathrm{Z} & - & >99.8 \% \\ \mathrm{SDV}(\mathrm{m}) & <0.2 \% & >99.8\end{array}$

Present state (2016)

\begin{tabular}{llll}
$\mathrm{C}_{\max }(\mathrm{m})$ & - & $4.2 \%$ & $0.4 \%$ \\
$\mathrm{Z}$ & - & $76.4 \%$ & - \\
$\mathrm{SDV}(\mathrm{m})$ & - & $89.5 \%$ & $50.9 \%$ \\
\hline
\end{tabular}

borderline values of the mean confidence intervals of these parameters for the class high in 83 stratified lakes in Poland (Fig. 4, Table 3). The maximum colonization depth $\left(\mathrm{C}_{\max }\right)$ was within the limits determined at a confidence level of $96 \%$ of the confidence interval for $\mathrm{C}_{\max }$ in those that were in a high ecological status. In summation, it can be confirmed that, in the mid twentieth century, the lake was in at least a good ecological status.

In August 2016, the ecological status of the lake had certainly deteriorated since none of the indicators analyzed permitted classifying it as the highest ecological status. The colonization index $\mathrm{Z}$ still indicated a good status, but the confidence level was lower (Table 3 ). The classification of the ecological status of the lake based on the remaining parameters was difficult because of the overlap of the mean values of the confidence intervals for SDV and $\mathrm{C}_{\max }$. Comparing mean values of ments.

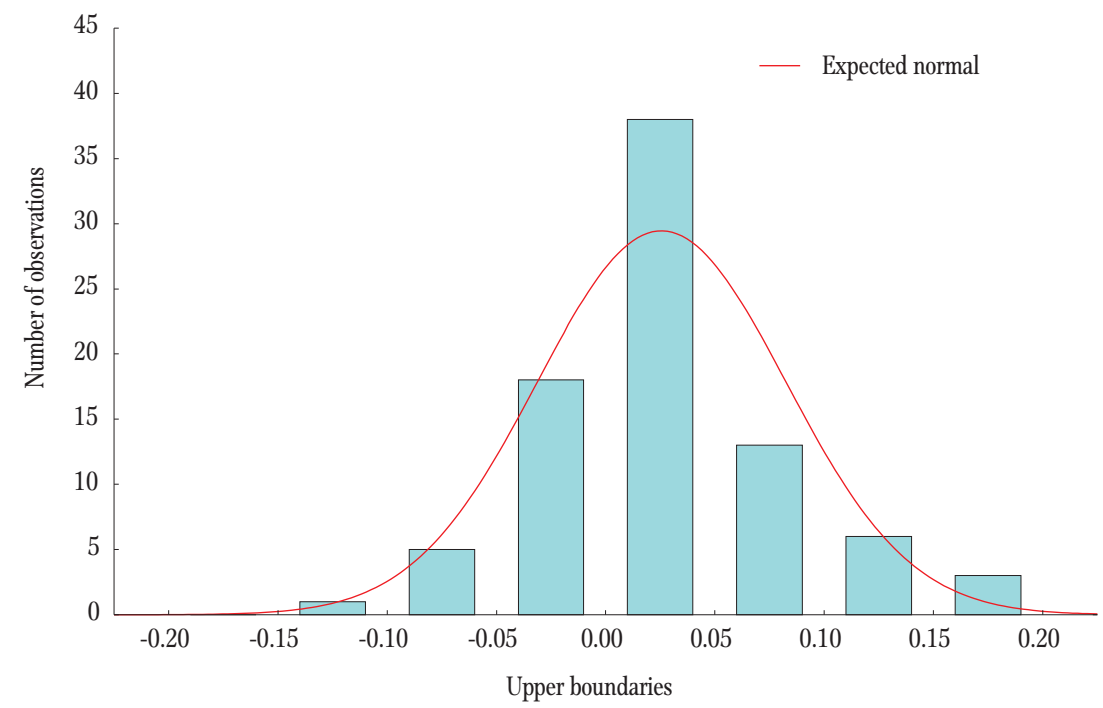

Figure 4. Distribution of relative errors $C_{\max }$ - maximum colonization depth was determined based on direct readings from echograms and by extrapolating depth measure- 


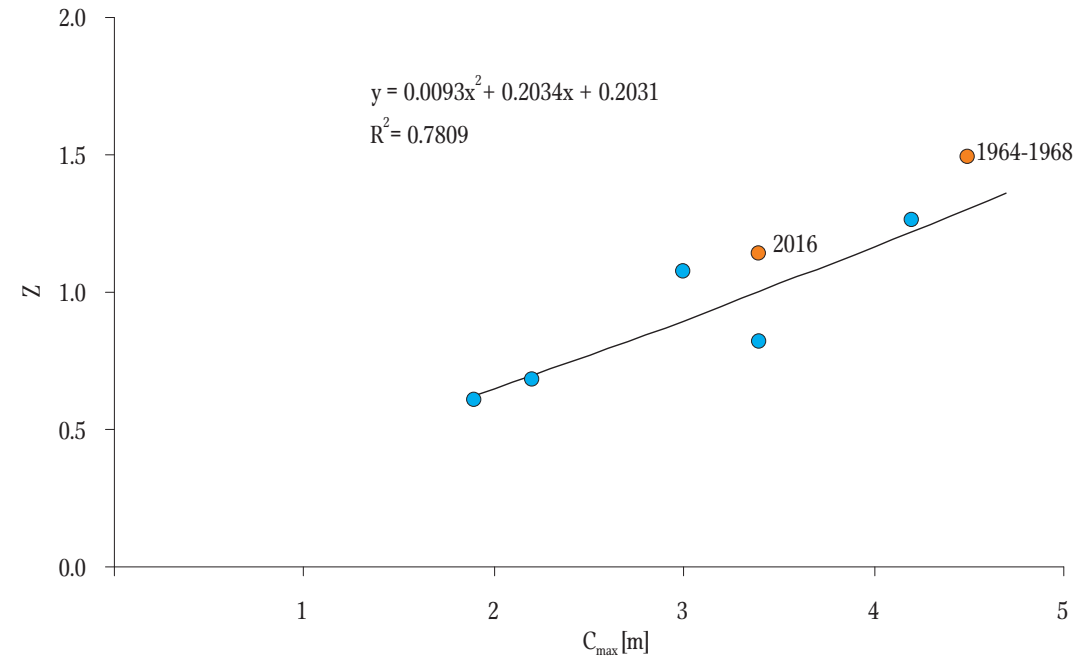

Figure 5. Relation of the colonization index $\mathrm{Z}$ and maximum colonization depth $\mathrm{C}_{\max }$ in five stratified lakes in the Welski Landscape Park (after Kolada et al. 2011) and in Lake Dobrąg in the mid 1960s and in 2016.

the lake status is on the border between good and moderate (Fig. 4, Table 3).

Uncertainty associated with assigning mean $\mathrm{C}_{\max }, \mathrm{Z}$, and SDV values to the appropriate confidence intervals for these averages in ecological status classes is not discussed in the literature a risk of misclassification based on the ESMI indicator
(Kolada et al. 2011, 2014). The risk of an erroneous assessment of ecological status based on biological evaluation could be caused by at least eight reasons that could cause errors at different stages of sampling and analysis (Clarke 2013). Erroneous assessment can stem, inter alia, from spatial and temporal differentiation of biological elements, the sample collection and preservation procedures applied, errors made while determining reference values, imprecision of the biological indicators used, improperly determined limits and broadnesses of status classes, and combining different biological indicators into a final multi-parameter indicator. Attempts to date of determining the risk of erroneous assessment in the modified Rejewski method indicate that if ESMI reaches values in the class limits, the risk of misclassification are $45-50 \%$, and this is higher for lower ecological status classes (Kolada et al. 2014).
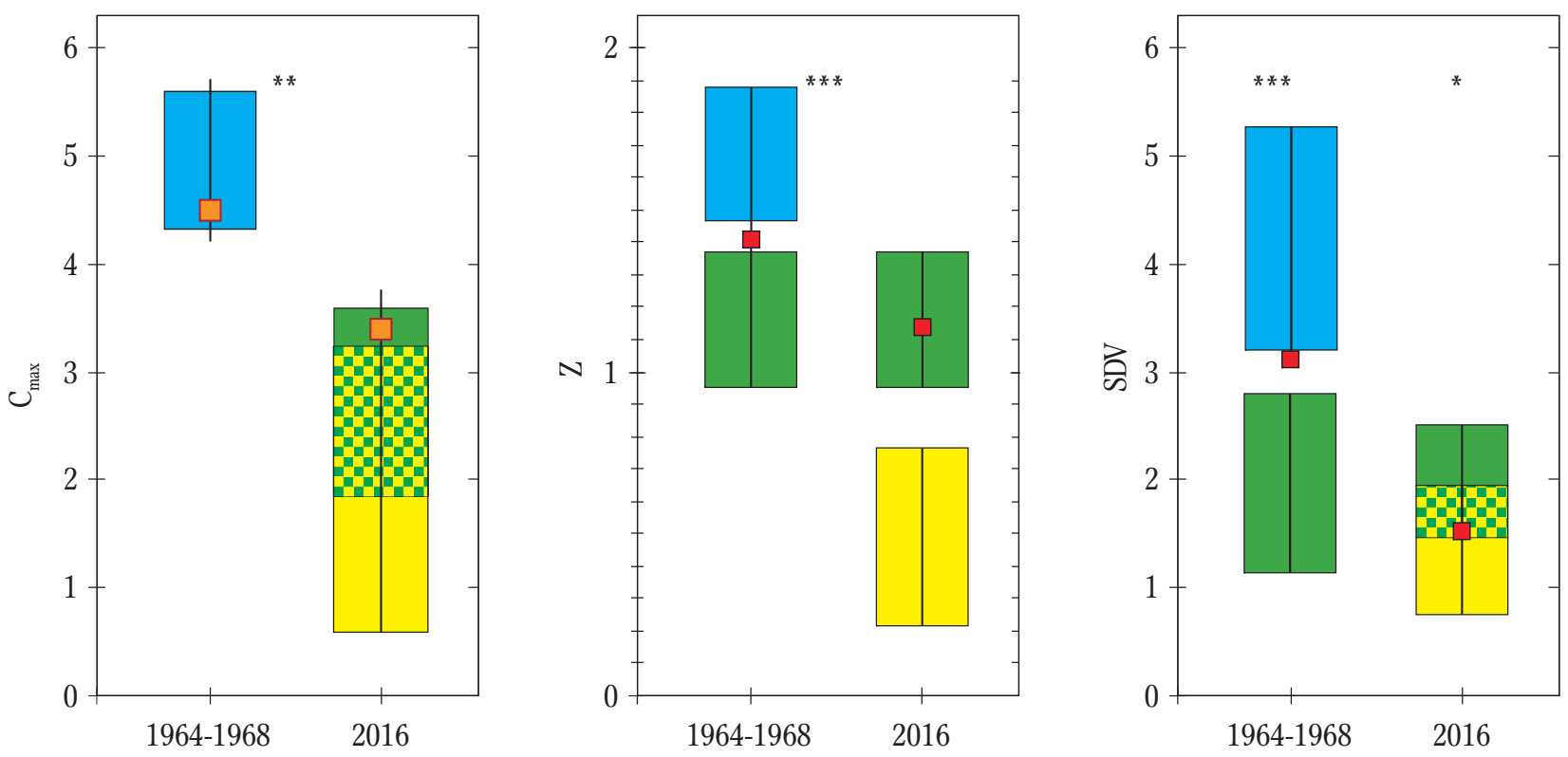

Figure 6. Comparison of index values using the Rejewski method: $\mathrm{C}_{\max }$ - maximum colonization depth (m), $\mathrm{Z}$ - colonization index, and SDV - Secchi depth visibility (m) in Lake Dobrąg in the 1960s and 2016 with the respective confidence intervals determined using the mean values of these indicators according to Ciecierska (2008) and Ciecierska et al. (2013); color coding of ecological status: blue - high; green - good; yellow - moderate; ${ }^{*}{ }^{*} \mathrm{P}<0.002,{ }^{*} \mathrm{P}<0.01,{ }^{*} \mathrm{P}<0.05$. 
When assessing ecological status based on selected indicators, which can be read from historic bathymetric charts (on which areas are marked that are overgrown with rushes and aquatic vegetation), it is only possible to determine the level of confidence of the assigned value compared with the means of these indicators in individual status classes. The uncertainty of an assessment done in this way only reinforces the risk of an incorrect assessment with the ESMI method. Thus, the proposed method cannot be used as an alternative to the original method. However, it does appear that the retroactive ecological assessment method, which permits classifying lakes possibly in accordance with the assessment based on the ESMI coefficient rating, could be helpful in attempts to assess changes in ecological status over the span of the past several decades.

Acknowledgments. This work was partially supported by the Inland Fisheries Institute (S-029) with grant funding for conducting research or development projects and for associated tasks that facilitate the development of young scientists which was awarded to the Inland Fisheries Institute in Olsztyn (grant No. IRS-046-39/2/1/2016).

Author contributions. All of the authors designed and performed the field measurements and methods; A.H. and M.B. analyzed the data, wrote the manuscript, and conducted the review of the literature.

\section{References}

Balk H., Lindem T. 2008 - Sonar4 and Sonar5-Pro post processing systems. Operator manual version 6.0.2 Lindem Data Acquisition A/S, p. 428.

Budzyńska D. 2007 - Report on the environmental status of the Warmian-Masurian Voivodeship in 2006 Biblioteka Monitoringu Środowiska, Olsztyn, p. 131. (in Polish).

Cendrowska M., Adamczyk M., Godlewska M., Puchalski W. 2015 - Using a fishery research echo sounder to measure submerged macrophytes - Komun. Ryb. 4(147): 17-21 (in Polish).

Cydzik D., Soszka H. 1988 - Atlas of the purity status of Polish lakes assessed in 1979-1983 - Wyd. Geologiczne, Warszawa, p. 607. (in Polish).
Ciecierska H. 2008 - Macrophytes as indicators of ecological status of lakes - Wyd. Uniwersytetu Warmińsko-Mazurskiego, Olsztyn, Poland, (in Polish, with English summary).

Ciecierska H., Kolada A., Ruszczyńska J. 2013 - Assessment of the ecological status of lakes based on macrophytes In: Biological methods for assessing environmental status. Vol. 2, Aquatic ecosystems (Eds) H. Ciecierska, M. Dynowska, Uniwersytet Warmińsko-Mazurski, Olsztyn: 106-128 (in Polish).

Clarke R.T. 2013 - Estimating confidence of European WFD ecological status class and WISER Bioassessment Uncertainty Guidance Software (WISERBUGS) Hydrobiologia, 704: 39-56.

Free G., Little R., Tierney D., Donnelly K., Caroni R. 2006 A reference based typology and ecological assessment system for Irish lakes. Preliminary investigations - Final report. Project 2000-FS -1-M1 Ecological Assessment of Lakes. Pilot Study to Establish Monitoring Methodologies EU (WFD ) - Environmental Protection Agency, Ireland. http://www.epa.ie/downloads/pubs/research/water/ final\%20report $\% 20$ (2000-fs1-m1).pdf

Jensen S. 1977 - An objective method for sampling the macrophyte vegetation in lakes - Vegetatio 33: 107-118.

Kolada A., Ciecierska H., Ruszczyńska J., Mjelde M., Dziedzic J., Dynowski P., Jasnorzewski A. 2011 - Macrophytes In: Ecological Status Assessment of the Waters in the Wel River Catchment. Guidelines for Integrated Assessment of Ecological Status of Rivers and Lakes to Support River Basin Management Plans (Ed.) H. Soszka, Wyd. IRS, Olsztyn: 169-186 (in Polish with English summary).

Kolada A.,Ciecierska H., Ruszczyńska J., Dynowski P. 2014 Sampling techniques and inter-surveyor variability as sources of uncertainty in Polish macrophyte metric for lake ecological status assessment - Hydrobiologia 737: 265-279.

Kondracki J. 1953 -The morphology of Lake Tajty - Roczn. Nauk Roln. 67-D: 9-22 (in Polish).

Knoben R.A.E., Roos C., van Oirschot M.C.M. 1995 - Biological assessment methods for watercourses - UN/ECE Task force on monitoring and assessment 5: 31-50.

RODW 2005 - Report for the Vistula Basin Area with the realization of art. 5 and 6, appendixes II, III, IV Water Framework Directive 2000/60/WE - 2005 - Available from URL: http://www.kzgw.gov.pl/files/file/Materialy_i_Informacje/ Raporty_i_opracowania/Raporty_do_Komisji_Europejskiej /Raport_Wis.pdf. Accessed 8 March 2017 (in Polish).

Rejewski M. 1981 - Lake vegetation in the Laski region of Bory Tucholskie - Wyd. Uniw. M. Kopernika, Torun, p. 178. (in Polish).

Schaumburg J., Schranz Ch., Hofmann G., Stelzer., Schneider S. 2004 - Macrophytes and phytobenthos as indicators of ecological status in German lakes - a contribution of the 
implementation of the Water Framework Directive Limnologica 34: 302-314.

WFD 2000 - EU, 2000. Directive 2000/60/EC of the European Parliament and of the Council of 23 Oct. 2000
Establishing a Framework for Community Action in the Field of Water Policy, OJEC L 327/1.

Fisheries Management Project 1969 - Principles for a fisheries management project for Lake Dobrąg - Biblioteka Instytutu Rybactwa Śródlądowego, manuscript (in Polish). 